\title{
Impact of nanosized aluminum hydroxide on the structural and mechanical properties of sugar beet tissue
}

\author{
Taras Nykytiuk ${ }^{1}$, Valentyn Olishevskiy ${ }^{1}$, \\ Evhen Babko ${ }^{1}$, Oleg Prokopiuk ${ }^{2}$
}

1 - National University of Food Technologies, Kyiv, Ukraine

2 - LLC "Teplocom"

Keywords:

Sugar beet

Shavings

Extraction

Nanosize

Aluminum

hydroxide,

Elasticity

\section{Article history:}

Received

05.05.2018

Received in

revised form

21.09.2018

Accepted

28.09.2018

Corresponding

author:

Taras Nykytiuk

E-mail:

tarasnykytiuk@

gmail.com
DOI:

$10.24263 / 2304-$

974X-2018-7-3-13

\section{Abstract}

Introduction. The study was conducted to confirm the feasibility of using aluminum hydroxide in the process of extracting sucrose from sugar beet shavings to increase the structural and mechanical properties of beet tissues.

Materials and methods. Investigation of the influence of aqueous solutions of additional reagents on the structural and mechanical properties of beet tissue by the method of hydraulic pressing of samples of sugar beet tissue of cylindrical shape from a geometric dimensional specification. Before that, each of the samples obtained was subjected to heat treatment in aqueous solutions of various reagents at a temperature of $70-72{ }^{\circ} \mathrm{C}$ with an experiment duration of 60 minutes.

Results and discussion. Processing of samples of beet tissue with additional solutions of aluminum sulfate, calcium sulfate, aluminum hydroxide and combinations thereof during extraction at a temperature of $70-72{ }^{\circ} \mathrm{C}$ will reduce the degree of deformation of samples of beet tissue compared to a sample that has not been treated with additional reagents. The degree of a beet tissue sample treated with a solution of nanosized aluminum hydroxide is $18 \%$ lower than the control sample without processing with additional reagents. This result can be explained by the high chemical activity of the aluminum hydroxide reagent. The ions of this compound are capable of forming in the surface layer of tissue fairly stable, insoluble complex compounds with pectin and protein substances, which, adsorbing on a layer of beet tissue, form something similar to the molecular framework, which increases the stability of beet tissue to compressive loads.

The quantity that can accurately describe the quality of beet tissue, its ability to restore its shape and elasticity during periodic compressive loads, is precisely the elastic modulus. During the heat treatment at a temperature of $70-72{ }^{\circ} \mathrm{C}$ the elastic modulus of samples of beet tissues, which was subjected to treatment with additional reagents, is $35-40 \%$ higher than a sample of beet tissue without processing with additional reagents.

Conclusions. Application in the process of extraction of nanosized aluminum hydroxide, will ensure the integrity of the structure of beet tissues in the processes of extraction and compression; ensures the high quality of extractant, diffusion and purified juice. 


\section{Introduction}

The speed and quality of the flow mass exchange processes in the extraction of sucrose from sugar beet shavings most significantly affect the structural and mechanical properties of beet tissue, such as its strength, elasticity and resilience. The traditional diffusion and press method for extracting sucrose from sugar beet shavings with the return of pulp-pressed water for extraction does not always provide the necessary degree of its extraction. The maximal effective extraction of sucrose from sugar beet shavings can be achieved in such a mode of the whole process, when beet tissue have optimal parameters of elasticity and durability. In view of this, today the issues of improving the structural and mechanical properties of sugar beet shavings, namely, the preservation of the integrity of the structure of its tissue in the process of juice extraction are relevant [1-6].

\section{Analysis of scientific research}

One of the modern directions of increasing the structural and mechanical characteristics of beet tissues is the use of chemical reagents in the process of extraction [7, $8,9]$. It is known that ions of polyvalent metals $\left(\mathrm{Ca}^{2+}, \mathrm{Fe}^{2+}, \mathrm{Fe}^{3+}, \mathrm{Al}^{3+}\right.$ etc. $)$ are able to bind polysaccharides of the cell walls of sugar beet shavings into insoluble complexes, thereby reducing the transition of non-sugars in diffusion juice. Therefore, the use of additional reagents will increase the elastic modulus of sugar beet shavings and, as a result, increase its transport and pressing characteristics.

In today's time, technology has become quite widespread with the use of minced natural gypsum - a sulfate-grade mineral or a slightly dissolved $\mathrm{CaSO}_{4}-\mathrm{Ca}\left(\mathrm{HSO}_{4}\right)_{2}$ salt obtained from a sugar plant through oxidation of factory lime milk with sulfur dioxide or sulfuric acid in the process of extraction $[10,11]$. But, the given method has a number of problems in application and does not give the desired result, namely - increase of structural and mechanical properties of beet shavings, on which directly the quality parameters of the intermediate products of sugar beet production are directly dependent.

Also, one of the directions of strengthening the beet shaving tissue in the traditional diffusion and press method of extracting sucrose from beet shavings, which has been developing intensively over the last decades, is the chemical effect on beet shavings by appropriate preparation of feed water for the extraction process $[12,13,14]$.

The use of additional reagents in the extraction process is essential for the intensification of the sugar beet pulp pressing process by improving its structural and mechanical properties. This problem in our time is extremely relevant due to the increase in prices for fuel materials, which negatively affects the technical and economic indicators of sugar beet pulp drying.

\section{Materials and methods}

The maximum effective production of sucrose from beet shavings can be achieved with a diffusion process in which the beetroot tissue has optimal strength and elasticity.

\section{Experimental installation}

Investigation of the influence of aqueous solutions of additional reagents on the structural and mechanical properties of beet tissues was carried out on a laboratory installation, presented in Figure 1. 


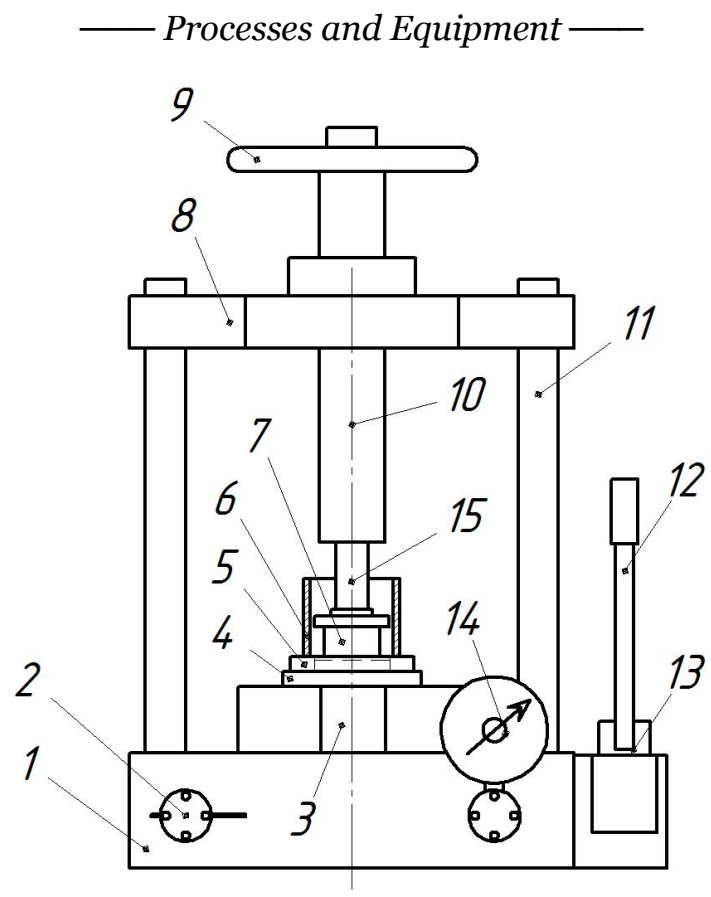

Figure 1. Scheme of an adapted laboratory installation for the study of structural and mechanical characteristics of sugar beet tissue:

1 - housing; 2 - final screw; 3 - tank; 4 - "heel"; 5 - perforated bottom; 6 - removable compression chamber; 7 - prototype; 8 - crossbeam; 9 - screw handle; 10 - clamping screw; 11 - rack;

12 - handle of the pump; 13 - hand pump; 14 - manometer; 15 - hydraulic cylinder.

The principle of hydraulic pressing is based on the installation. The laboratory press (Figure 1) consists of a housing 1, vertical racks 11, to which the crossbeam 8 is attached. On "the heel" 4 is placed a removable compression chamber 6 with a perforated bottom 5. Rotation of the handle of the screw 9 presses the prototype to the pressure screw 10. using the pump handle 12 pumps oil into the hydraulic cylinder 15 and vertically lifts "the heel" 4. Pressure is controlled by a manometer 14 .

The use of this engineering compression equipment provided a high pressure of compaction of the test material to a state with a small (close to zero) volume content of the gas-liquid phase [9].

During pressing, depending on the structural changes taking place in the sample of a disperse material of a given volume, 4 press zones can be conventionally identified (Figure 2).

At the 1st stage of pressing, the dispersion medium (air, water) is displaced from the volume of the material; the process is characterized by a slight increase in pressure with significant movements of the poisson.

At the second stage, the dispersion of the directly dispersed phase takes place; the process is characterized by a reduction in the displacement of the poisson and a gradual increase in pressure. 
At the third stage, the gas-liquid phase is displaced from the volume of solid particles of the material; the process is characterized by a significant increase in pressure with small displacements.

At the fourth stage, the components of the dispersed phase (cell destruction) are condensed with a sudden increase in pressure and an insignificant amount of displacement of the poisson.



Figure 2. Graph of pressure dependence $P$ on linear deformation $H$ when pressing a disperse test sample

\section{Method}

Investigation of the structural and mechanical characteristics of sugar beet tissue was carried out as follows: from the root of sugar beet, samples of cylindrical shape with a diameter of $d 50 \mathrm{~mm}$ and a thickness (height $h$ ) of $25 \mathrm{~mm}$ were obtained. Each of the samples obtained was subjected to heat treatment in aqueous solutions of various reagents at a temperature of $70-72{ }^{\circ} \mathrm{C}$ with an experiment duration of 60 minutes $[15,21]$.

\section{Materials}

As reagents, solutions of $\mathrm{CaSO}_{4}, \mathrm{Al}_{2}\left(\mathrm{SO}_{4}\right)_{3}$ and nanosized aluminum hydroxide $\mathrm{Al}(\mathrm{OH})_{3}$ (Fig. 3), obtained by the method of underwater electrospark synthesis [Patent $38461 \mathrm{UA}]$ and a combination of aqueous solutions of these reagents were used. Ratio, reagent concentrations and laboratory results of qualitative indices of diffusion juice are described in Table 1.

\section{Order of research}

After the end of the extraction process, the prototypes were placed in the chamber 6 of the laboratory installation and pressings were carried out in the effort range of $0.5-2.5 \mathrm{MPa}$. At the same time, structural changes and geometric shapes of beet tissue samples, namely, the height $h$, before and after the compressive loads, were measured. The results were compared with control samples of partially desiccated beetroot tissue [16, 17]. 


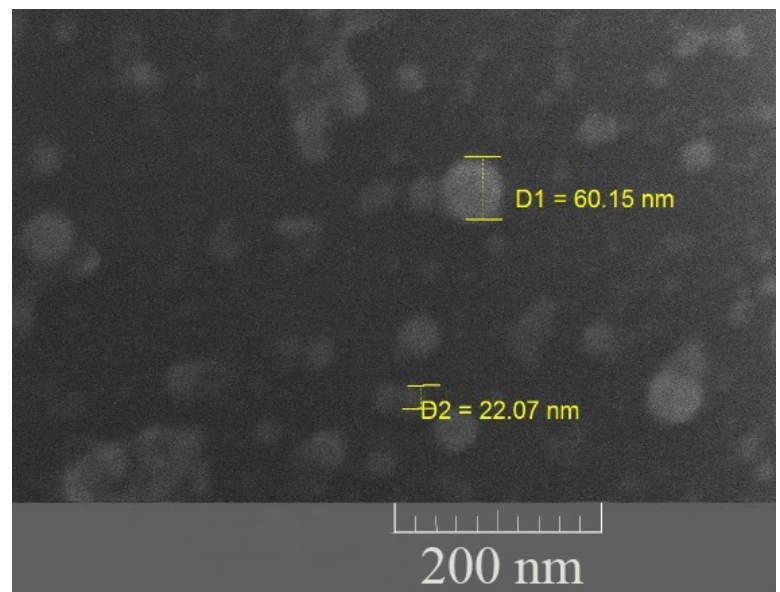

Figure 3. Electron microscopic image of nanosized aluminum hydroxide $\mathrm{Al}(\mathrm{OH})_{3}$

\section{Processing of research results}

The main criterion for determining the degree of quality of beet tissue is its ability to restore its shape and elasticity under periodic compressive loads during extraction and subsequent pressing in production conditions. The magnitude, exactly can describe the quality of the beet tissue, is precisely the elastic modulus [16-20].

The elastic modulus was determined according to Hooke's law with respect to:

$$
E=\frac{G}{\varepsilon}
$$

where: $G$ - the tension caused in the sample by the acting force; $\varepsilon$ - the elastic deformation of the sample caused by stress.

$$
G=\frac{P}{F}
$$

where: $P$ - the compression force applied to the sample; $F$ - the cross-sectional area of the sample.

$$
\varepsilon=\frac{\Delta h}{h}
$$

where: $\Delta h$ - change in the size of the sample after deformation; $h$ - the initial size of the sample to the action of the force.

\section{Results and discussion}

The results of the study of the influence of nanosized $\mathrm{Al}(\mathrm{OH})_{3}$ aluminum hydroxide on the structural and mechanical characteristics of beet pulp are shown in Figure 4 and in Table 1. 
Table 1

Impact of aqueous solutions of additional reagents on qualitative indices of diffusion juice and on structural and mechanical characteristics of beet tissue

\begin{tabular}{|c|c|c|c|c|c|c|c|c|c|c|}
\hline \multirow{2}{*}{ 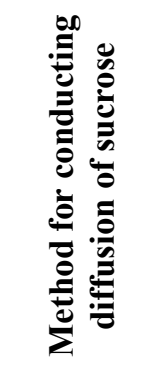 } & \multicolumn{2}{|c|}{ Concentrations } & \multicolumn{3}{|c|}{ Diffusion juice } & \multirow{2}{*}{ 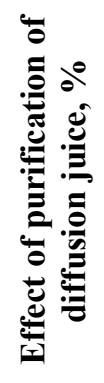 } & \multirow{2}{*}{ 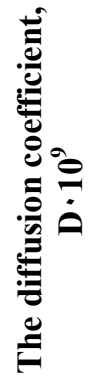 } & \multicolumn{2}{|c|}{ E, MPa } & \multirow{2}{*}{ 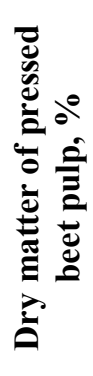 } \\
\hline & C1 & C2 &  & 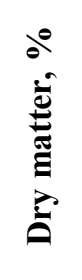 &  & & & E1 & E2 & \\
\hline Typ & & & 3 & 16,9 & 53 & 15,04 & 0,048 & 6,1 & 95 & 23,5 \\
\hline $\mathbf{A l}_{2}\left(\mathbf{S O}_{4}\right)$ & 10 & & & 17,3 & 92,01 & 29,3 & 0,077 & & & 24,2 \\
\hline $\mathrm{CaSO}_{4}$ & 10,0 & & & 16,9 & 91,2 & 21,45 & 0,057 & 6 , & & 25,8 \\
\hline $\mathrm{Al}(\mathrm{OH})_{3}$ & 0 , & & 15 & 16,6 & 92 & 37,8 & 0,130 & 6 & 1 & 27,0 \\
\hline $\begin{array}{l}\mathrm{Al}_{2}\left(\mathbf{S O}_{4}\right)_{3} / \\
\mathrm{CaSO}_{4}\end{array}$ & $\begin{array}{l}10, \\
10,\end{array}$ & & 15 & 17,0 & 8 & 02 & 6 & 6,1 & 1,31 & 26 \\
\hline $\begin{array}{l}\mathbf{A l}_{2}\left(\mathbf{S O}_{4}\right)_{3} / \\
\mathrm{CaSO})_{4} / \\
\mathrm{Al}(\mathbf{O H})_{3}\end{array}$ & $\begin{array}{c}10,0 / \\
10,0 / \\
0,2 \\
\end{array}$ & $\begin{array}{r}0,0 \\
0,0 \\
0,00\end{array}$ & 15,9 & 17,1 & 93,0 & 38,73 & 0,110 & 6,1 & 1,35 & 27,3 \\
\hline $\begin{array}{l}\mathrm{Al}_{2}\left(\mathrm{SO}_{4}\right)_{3} / \\
\mathrm{Al}(\mathrm{OH})_{3}\end{array}$ & $\begin{array}{c}10,0 / \\
0,2 \\
\end{array}$ & $0,02 /$ & 16,07 & 17,3 & 92,9 & 37,8 & 0,101 & 6,1 & 1,28 & 27,2 \\
\hline $\begin{array}{l}\mathrm{CaSO}_{4} / \\
\mathrm{Al}(\mathrm{OH})_{3}\end{array}$ & $\begin{array}{c}10,0 / \\
0,2 \\
\end{array}$ & $\begin{array}{c}0,04 / \\
0,0015\end{array}$ & 15,6 & 16,9 & 91,8 & 27,3 & 086 & 6,1 & 1,22 & 26,8 \\
\hline
\end{tabular}

where: $\mathrm{C}_{1}-$ Concentrations of reagents in solution, $\%$;

$\mathrm{C}_{2}-$ Concentrations of reagents to the mass of beet shavings, \%;

$\mathrm{E}$ - elastic modulus of sugar beet tissue;

$\mathrm{E}_{1}$ - before extraction;

$\mathrm{E}_{2}-$ after extraction.

\section{Effect of nanosized aluminum hydroxide on the degree of deformation of sugar beet tissue}

Analyzing the diagram of deformation changes (Figure 3), it can be said that the processing of beet tissue samples with additional solutions of $\mathrm{Al}_{2}\left(\mathrm{SO}_{4}\right)_{2}, \mathrm{CaSO}_{4}, \mathrm{Al}(\mathrm{OH})_{3}$ and their combinations during extraction at a temperature of $70-72{ }^{\circ} \mathrm{C}$ will reduce the degree of deformation of the samples beet tissue compared with a sample that has not been treated with additional reagents. In addition, it should be especially noted that the degree of the beet tissue sample that was treated with $\mathrm{Al}(\mathrm{OH})_{3}$ solution is $18 \%$ lower than the control sample without treatment with additional reagents (Figure 5). Such an increased stability of beet tissue samples, as well as its rigidity and the ability to resist deformation under the action of force, can be explained by the high chemical activity of the $\mathrm{Al}(\mathrm{OH})_{3}$ reagent $[15$, 21]. The ions of this compound are capable of forming in the surface layer of the tissue sufficiently stable insoluble complex compounds with pectin and protein substances, which, adsorbed on a layer of beet tissue, form something like a molecular framework that 
increases the stability of beet tissue to compressive loads. Describing Figure 5 , it is worth mentioning that in sample $5 c$, there is a part of non-deformable cellular structures of beet tissue in a much larger amount than in sample $5 b$, which indicates an increase in the stability of beetroot tissue treated with $\mathrm{Al}(\mathrm{OH})_{3}$ solution and approximation of its elastic characteristics to the tissue sample fresh sugar beet $5 a$.

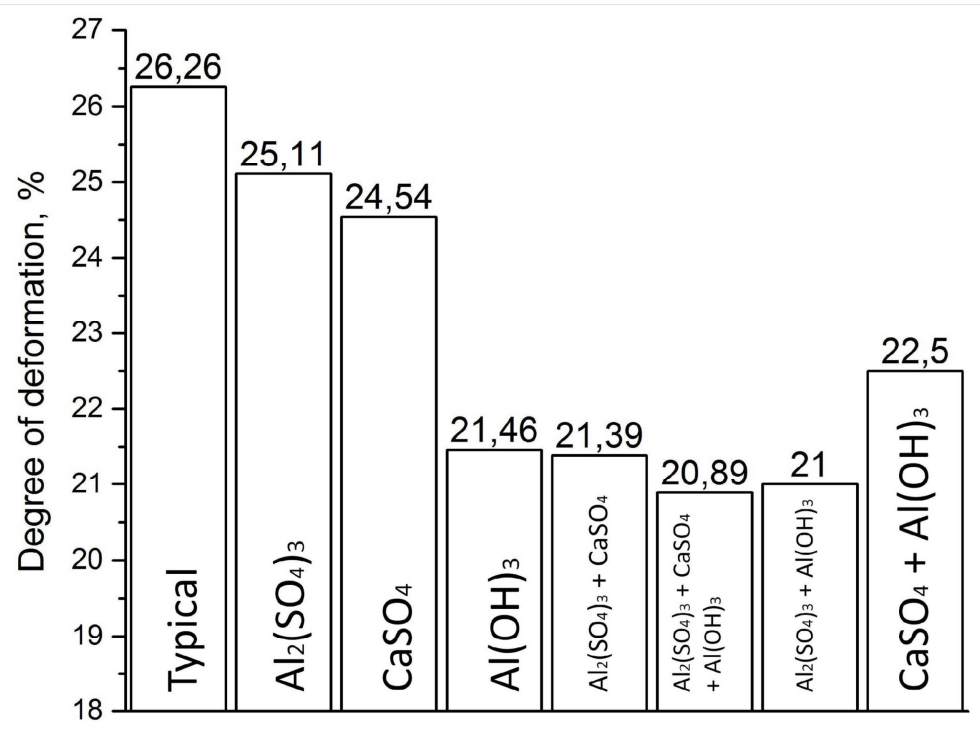

Reagents for the treatment of sugar beet tissue

Figure 4. Indicators of deformation changes in samples of beet tissue using different reagents in the sucrose extraction process at a temperature of $70-72^{\circ} \mathrm{C}$

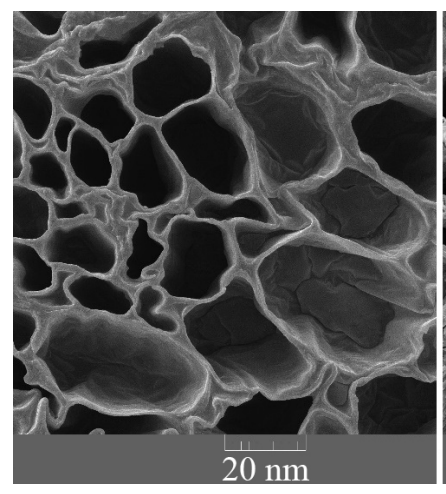

$a$

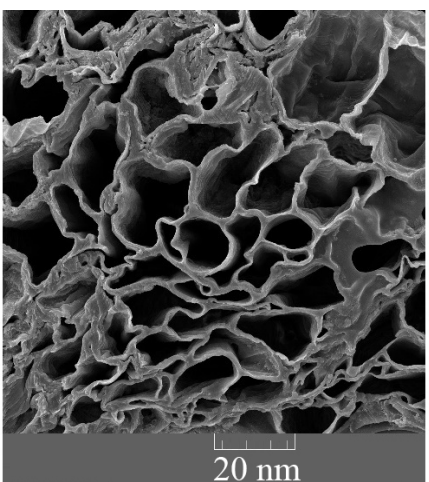

b

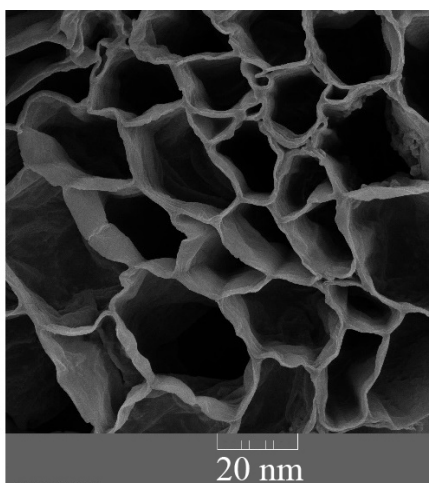

c

Figure 5. Electron microscopic image of sugar beet tissue samples after compressive loads: a - tissue of fresh sugar beet;

b - sample of sugar beet tissue without finishing with additional reagents in the extraction process;

c - sample of sugar beet tissue with the addition of reagents, which included $\mathrm{Al}(\mathrm{OH})_{3}$ during the extraction. 


\section{Effect of nanosized aluminum hydroxide on the elastic modulus of sugar beet tissue}

The next stage of the work was study the effect of the use of additional reagent solutions in the extraction process on the elastic modulus of sugar beet tissue.

Sugar beet tissue has the ability to partially restore its elasticity when it is watersaturated and at a temperature that causes its thermal denaturation $[15,21]$. It is obvious that during the extraction process in batch production plants, the beet shavings absorb moisture and under high temperatures are destroyed. As the temperature of the process increases, high-molecular compounds from less stable tissues pass into solution, the geometry of the sugar beet shavings changes, the hydrodynamic conditions in the diffusion apparatus deteriorate, the permeability of the co-extrusion mixture and, consequently, the purity of the diffusion juice deteriorates [15, 21, 22, 23].

The size of the elastic modulus depends on the turgor of the tissue, which, in turn, depends on the directivity of the functioning of the cell membranes, so the factors that negatively affect the turgor also reduce the elastic modulus. So, for healthy sugar beets, the elastic modulus ranges from 6 to $14 \mathrm{MPa}$.

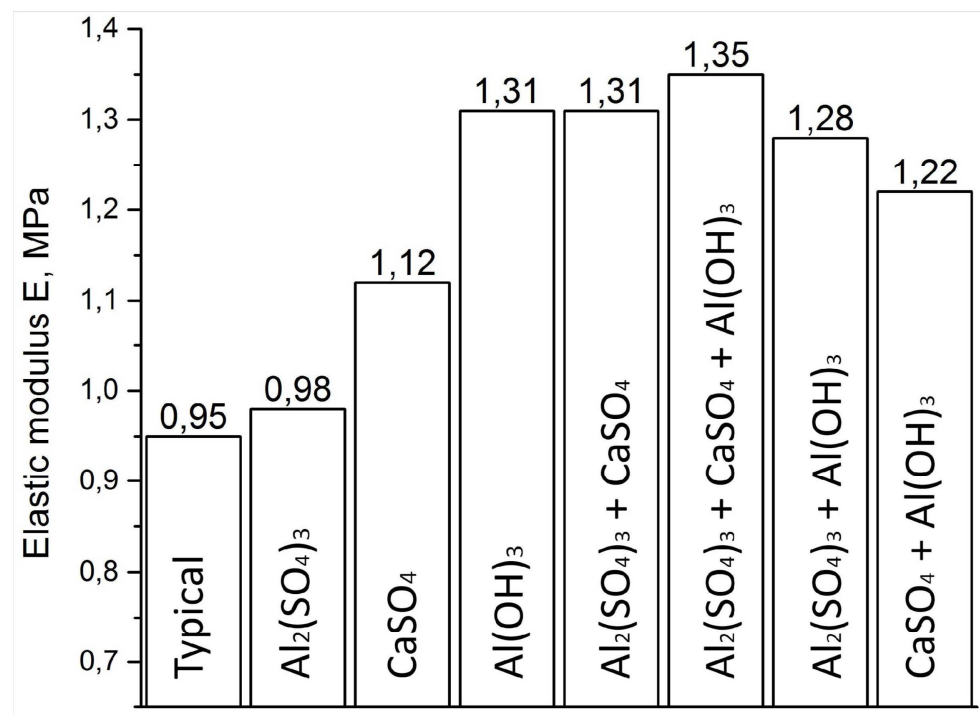

Reagents for the treatment of sugar beet tissue

Figure 6. Indicators of the elastic modulus of sugar beet tissue samples when using various reagents in the extraction of sucrose at a temperature of $70-72{ }^{\circ} \mathrm{C}$.

The results of the studies presented in Table 1 were obtained by statistical processing of data from a series of experiments $[15,21]$. The accuracy of the measurement results and calculations of the elastic modulus is within 3\%, which indicates a fairly high accuracy and reliability of the research results. The advantages of this modified and adapted method for the determination of structural and mechanical characteristics should also include the not 
very high complexity of carrying out measurements and calculations, which will allow the fastest control of the elastic characteristics of beet tissue under production conditions.

From the graph of the values of the elastic modulus shown in Figure 6, it follows that during the heat treatment at a temperature of $70-72{ }^{\circ} \mathrm{C}$ the elastic modulus of beet samples was treated with additional reagents by $35-40 \%$ higher than a sample of beet tissue without finishing with additional reagents. This qualitative difference will ensure the stability of the beet shavings to the external factors and will provide the necessary elasticity in the processes of extraction and subsequent compression under production conditions.

\section{Effect of nanosized aluminum hydroxide on the moisture retention capacity of sugar beet tissue}

Based on the results shown in Figure 7, it can be said that, with the same degree of pressing of the beet shavings, more moisture is removed when the additional reagent $\mathrm{Al}(\mathrm{OH})_{3}$ is used in the extraction process. Therefore, it can be argued that the use of an additional reagent $\mathrm{Al}(\mathrm{OH})_{3}$ alone or in combination with other reagents in the process of extraction of sucrose from beet shavings allows to achieve a high degree of dehydration of beet pulp that reduces the energy costs for the processes is about further pressing and drying. In addition, such results of water retention capacity indicate that the use of $\mathrm{Al}(\mathrm{OH})_{3}$ additional reagent in the process of extraction will increase the quantity and quality of pulppress water, guarantees the production of a reduction in economic costs and improvement of the ecological situation around the sugar plant.



Reagents for the treatment of sugar beet tissue

Figure 7. The content of dry substances in samples of sugar beet tissue with the same degree of pressing when using different reagents in the extraction of sucrose at a temperature of $70-72{ }^{\circ} \mathrm{C}$ 


\section{Conclusions}

1. All additional reagents improve the elastic characteristics of the beet tissue, while the nano-sized aluminum hydroxide $\mathrm{Al}(\mathrm{OH})_{3}$ alone or in combination with other reagents showed that it is its presence in the solution of the additional reagent that guarantees the best structural and mechanical properties of the sugar beet tissue.

2. Application in the process of extraction of nanosized aluminum hydroxide $\mathrm{Al}(\mathrm{OH})_{3}$, obtained by the method of underwater electrospark synthesis, will ensure the integrity of the structure of sugar beet tissue in the processes of industrial extraction and pressing; guarantees high quality of extractant, diffusion and purified juice.

3. The nanosized aluminum hydroxide $\mathrm{Al}(\mathrm{OH})_{3}$, in comparison with conventional reagents, is economically and technologically promising for use in the extraction and pressing of sugar beetroot shavings. The use of the proposed method for determining the elastic modulus of a sugar beet sample will allow accurately and promptly control the structural and mechanical characteristics of the raw material during its storage and processing, which allows optimizing the process of extraction of sucrose and compression of the pulp and, thus, improving the yield and quality of the target product.

\section{References}

1. Asadi M. (2007), Beet Sugar Handbook, John Wiley and Sons, Hoboken, New Jersey, pp. 162 163, pp. 435-450.

2. Bogdanovic, Branislav V., Seres, Zita I., Gyura, Julianna F. (2013), The influence of extraction parameters on the quality of dried sugar beet pulp, Hemijska industrija, 67(2), pp. 269-275

3. Ermanno Prati, Franco Maniscalco (2013), How to improve the performance of pulp pressing? Sugar industry-zuckerindustrie, 138(3), pp. 171-174.

4. Ermanno Prati, Franco Maniscalco (2013), Recommendations on how to increase the sugar beet pulp press efficiency, International sugar journal, 115(1373), pp. 339-343.

5. Ermanno Prati (2015), The role and the influence of fine pulp in sugar beet processing, Sugar industry-zuckerindustrie, 140(6), June, pp. 370-374.

6. Ermanno Prati (2016), Impact of fine pulp during sugar beet processing, International sugar journal, 118 (1406), pp. 118-121.

7. Tovar Jose Carlos et al. (2015), Plant Pectin Methylesterase Treatments Dramatically Reduce Water-binding in Sugar Beet Pulp via Calcium Crosslinking, Arkansas State University, Arkansas.

8. Bosse E.D. (1997), Increase in dry substance of pressed pulp by addition of pressing aids into the pulp press, 29th General Meeting of the American Society of Sugar Beet Technologists Phoenix, Arizona March 2 to 5, pp. 233-235.

9. Ueli Wyss, Catherine Metthez, Yves Arrigo, (2015), Silage quality: pressed sugar-beet pulp with added molasses, Agrarforschung schweiz, 6(9), pp. 416-423.

10. Osadchy L. (2013), Use of gypsum in the diffuse process of sugar beet production, Journal of Sugarcorns of Ukraine, 6(85), pp. 13-17.

11. Costa Crusciol, C. A., Foltran, R., Rossato, O. B., et al. (2014) Effects of surface application of calcium-magnesium silicate and gypsum on soil fertility and sugarcane yield, Revista Brasileira De Ciencia Do Solo, 38(6), pp. 1843-1854.

12. Gul S., Ahmed A. El Gohary Harasek, M. (2012), Beet sugar pulp-press water treatment: A comparison of nanofiltration and reverse osmosis processes, Euromembrane Conference, London, England, September 23-27, Procedia Engineering, 44, pp. 634-634. 
13. Mareike Monninger (2017), Measuring water content of pressed beet pulp - microwave transmission measurement for process optimization and quality improvement, Sugar industryzuckerindustrie, 142(11), November, pp. 648-650.

14. Yapo B.M., Robert C., Etienne I., Wathelet B., Paquot M. (2007), Effect of extraction conditions on the yield, purity and surface properties of sugar beet pulp pectin extracts, Food Chemistry, 100(4), pp. 1356-1364.

15. Ukrainets A., Olishhevskyi V., Pushancko N., Babko E., Nykytiuk T. (2016), Development of resource-saving process of extraction of sucrose from sugar beet using aluminum nanocomposite, Improvement of processes and equipment - a pledge of innovative development of the food industry, materials of the interface. science-practice Conf., 8-10 November, Kyiv, NUFT, pp. 117-119.

16. Chee Kiong Siew, Peter A. Williams (2008), Role of Protein and Ferulic Acid in the Emulsification Properties of Sugar Beet Pectin, Centre for Water-Soluble Polymers, North East Wales Institute, Plas Coch, Mold Road, Wrexham LL11 2AW, United Kingdom, J. Agric. Food Chem., 56(11), pp. 4164-4171.

17. Xin Huanga, Dong Li, Li-jun Wanga (2017), Characterization of pectin extracted from sugar beet pulp under different drying conditions, Journal of Food Engineering, 211, October, pp. 16.

18. Belyaeva L., Chugguaunov A., Ozerov D., Anateeva P. (2007) Investigation of the elasticity of sugar beet tissue, Sugar, 5, pp. 22-24.

19. Xin Huanga, Dong Li, Li-jun Wanga (2017), Effect of Drying Methods on the Rheological Properties of Sugar Beet Pulp Pectin, International Journal of food engineering, 13(4), № 20160165.

20. Xin Huanga, Dong Li, Li-jun Wanga (2018), Effect of particle size of sugar beet pulp on the extraction and property of pectin, Journal of food engineering, 218, pp. 44-49.

21. Olishhevskyi V., Ukrainets A., Lopatko K., Pushancko N., Babko E., Vilchenko A., Kostiuchenko V., Marynin A., Nykytiuk T., Lapshin S., (2016), Experience of using nanocomposite of aluminum in beet-sugar production, Sugar of Ukraine, 11-12(131-132), pp. $11-17$.

22. Xiaobing Guo, Xiaoming Guo, Shujuan Yu (2018), Influences of the different chemical components of sugar beet pectin on the emulsifying performance of conjugates formed between sugar beet pectin and whey protein isolate, Food Hydrocolloids, 82, pp. 1-10.

23. Guanhua Li, Yanxin Sun, Wenjing Guo (2018), Comparison of various pretreatment strategies and their effect on chemistry and structure of sugar beet pulp, Journal of cleaner production, 181, pp. 217-223. 